Bangladesh J. Bot. 39(2): 143-151, 2010 (December)

\title{
PHYTOPLANKTON STANDING CROP AND ITS DIVERSITY IN THE BURAGAURANGA RIVER ESTUARY IN RELATION TO CHEMICAL ENVIRONMENT*
}

\author{
Ashfaque Ahmed**, Sirajul Hoque ${ }^{1}$, Mikael Ohlson, \\ Md Abdus Salam AKanda ${ }^{2}$ and Md Golam Moula ${ }^{3}$ \\ Department of Ecology and Natural Resource Management, \\ Norwegian University of Life Sciences, Ås-1432, Norway
}

Key words: Phytoplankton standing crop, Diversity, Estuary, Chemical environment, Bangladesh

\begin{abstract}
Chemical and biological features of Buragauranga river estuary stretching about eight kilometers beside Rangabali of Galachipa Upozilla, Patuakhali district, Bangladesh showed that the water of the estuary was moderately alkaline $(\mathrm{pH} 7.8-8.21)$. Conductivity had moderate to very strong and perfect significant correlations (at 5\% level) with the chemical variables. Magnesium was found to have very strong relationship with different fractions of hardness whereas Ca had moderate correlation. The phytoplankton community was represented by 10 genera belonging to Chlorophyceae, Euglenophyceae and Bacilariophyceae. Bacillariophyceae was the dominant algal class (8 genera, 80\%). Trachelomonas sp. of Euglenophyceae was present in all the 12 sampling units of 3 locations indicating its dominancy and capacity to tolerate habitat fluctuations. Location 2 showed higher generic diversity than the other two locations. Principal component analysis showed that Trachelomonas sp. has negative significant correlation with principal component one i.e. Mg, K, conductivity, dissolved oxygen, biological oxygen demand and salinity have negative effect on the distribution of Trachelomonas sp. whereas these variables have positive effects on Coscinodiscus sp.
\end{abstract}

\section{Introduction}

An estuary acts as a linkage between the drainage basin and sea at the coast and also as a filter and recorder of river catchments changes due to human activities (Chen et al. 2007). A variety of complex physicochemical processes resulted in the poor understanding of estuaries of all coastal systems though studied most, and various factors such as growth of human population, agriculture and changes in land use pattern in the watershed have resulted in an increase of nutrient input to the estuaries of the world (Caffrey et al. 2007). The estuaries and coastal systems of different parts of the world faced hypoxia and anoxia due to excessive algal growth and eutrophication.

About 6000 years ago the coastal zone of Bangladesh started to form and it is the lowest-lying part of the Himalayan river-basin ecosystem (Islam 2001). But there is little comprehensive survey to determine the oceanographic features and organic productivity of the Bay of Bengal and its estuary which resulted in a general lack of basic information (Wyritki 1971, Krey 1976). Islam and Aziz $(1975,1977)$ have described and illustrated the phytoplankton and water chemistry of the Bay of Bengal and phytoplankton of the Karnaphuli river estuary. Except this, other parts of the estuarine ecosystems of Bangladesh such as Khulna, Barisal and Patuakhali areas remain almost unstudied. However, Ahmed et al. (2010 a, b) studied the edaphic conditions of different offshore islands with different hydrological regimes, elemental concentrations of the leaves of mangrove tree Sonneratia apetala Buch.-Ham, from the estuary of Patuakhali, but no information does exist on water and phytoplankton quality from the same area.

*Part of the MS thesis of the first author. **Corresponding author. E-mail: <aashfaque67@yahoo.com>. Present address: Ecology and Environment Laboratory, Department of Botany, University of Dhaka, Dhaka-1000, Bangladesh. ${ }^{1}$ Department of Soil, Water and Environment, University of Dhaka, Bangladesh, ${ }^{2}$ Department of Statistics, Biostatistics and Informatics, University of Dhaka, Bangladesh, ${ }^{3}$ Plantation Trial Unit Division, Bangladesh Forest Research Institute, Rupatoli, Barisal, Bangladesh. 


\section{Materials and Methods}

Buragauranga river estuary, Patuakhali $\left(21^{\circ} 53^{\prime} 10^{\prime \prime}-22^{\circ} 00^{\prime} 00^{\prime \prime} \mathrm{N}\right.$ and $90^{\circ} 27^{\prime} 00^{\prime \prime}-90^{\circ} 30^{\prime} 30^{\prime \prime}$ E), situated about $300 \mathrm{~km}$ south of Dhaka Metropolis, was studied. Three locations were selected and these were: Location 1: across the river near Char Motherbunia; Location 2: east of Char Taposhi and Location 3: between the Char Taposhi and Char Kashem, details of which are available in Ahmed et al. (2010a). Engine driven country boat was used in sampling on 28th February 2006 during high tide.

At each station $\mathrm{pH}$, conductivity, free $\mathrm{CO}_{2}$, salinity and dissolved oxygen (DO) of water were measured by using respective field meters. Four replicates of water samples, each $500 \mathrm{ml}$ in quantity were collected from each location from a depth of $60 \mathrm{~cm}$ with the help of a water sampler (Lakshminarayana 1965, Ahmed 2004). Water samples were also collected for measuring the diversity of phytoplankton via sedimentation technique. For these purpose $100 \mathrm{ml}$ capacity plastic bottles each containing $200 \mu \mathrm{l}$ Lugols iodine were used. After collection, all samples were brought to the Department of Soil, Water and Environment, University of Dhaka for laboratory analyses. The concentration of chloride, $\mathrm{BOD}_{5}$ (at $25 \pm 3^{\circ} \mathrm{C}$ ), hardness, filtrable and non-filtrable total residue were determined according to APHA (1976). Alkalinity was determined by the method described by Wetzel and Likens (1979). Na and K were determined by flame photometry and Ca and Mg by atomic absorption spectrophotometer. Sulphate was measured by the method of Hunt (1980). The density of phytoplankton was determined with the help of a Sedgewick-rafter counting chamber (Wetzel and Likens 1979).

Chemical variables of water were subjected to the ANOVA. Locations were used as factors. To compare water samples of the three locations of the river Buragauranga, ANOVA was performed using general linear model procedures in SAS 9.1 program. For the measurement of generic diversity the Shannon-Weiner diversity index $(\mathrm{H})$ was calculated following Ruggiero and Merchant (1979). Principal component analysis (PCA) was done by using Stata 11 program (Stata 2010).

\section{Results and Discussion}

The chemical variables of Buragauranga river estuary on 28 February 2006 during high tide are shown in Fig. 1. Location 3 significantly differed from location 2 in salinity, non-filtrable residue, and total residues content only. Other variables did not show significant differences. On the other hand, location 3 showed significant differences from location 1 on salinity, non-filtrable residue, total residue, $\mathrm{DO}$, oxygen saturation, $\mathrm{BOD}_{5}$, permanent, temporary and total hardness and in $\mathrm{Mg}$ content.

Location 1 showed highest value for free $\mathrm{CO}_{2}$ content with the concomitant of lowest DO. Higher value of conductivity in the location 2 of the river Buragauranga might be due to shallow nature of the place, and the area was also characterized by higher filterable residues. Lower conductivity and salinity in the location 1 can be explained by higher mixing of fresh water in this zone as it is far away from sea than locations 2 and 3. Safe standard of DO concentration in estuary was a median value of $7 \mathrm{mg} / \mathrm{l}$ with changes of $<1 \mathrm{mg} / \mathrm{l}$ (Painting et al. 2007). But in the present study a high median value $11.2 \mathrm{mg} / \mathrm{l}$ was observed. The minimum and maximum values were observed 7.7 and $12.0 \mathrm{mg} / \mathrm{l}$, respectively. In a study of Biscayne Bay, Florida, the median DO was found to be $6.3 \mathrm{mg} / \mathrm{l}$ with minimum and maximum values ranged between 2.8 and 11.6 $\mathrm{mg} / \mathrm{l}$ (Caccia and Boyer 2005). $\mathrm{DO}_{\text {sat }}$ values had been found within a range of 41.1 - $161.0 \%$ with the median $92.0 \%$ in the same study. The present study showed that the values of both DO and $\mathrm{DO}_{\text {sat }}$ were in between the ranges of Biscayne Bay. The primary sources of oxygen in the marine 

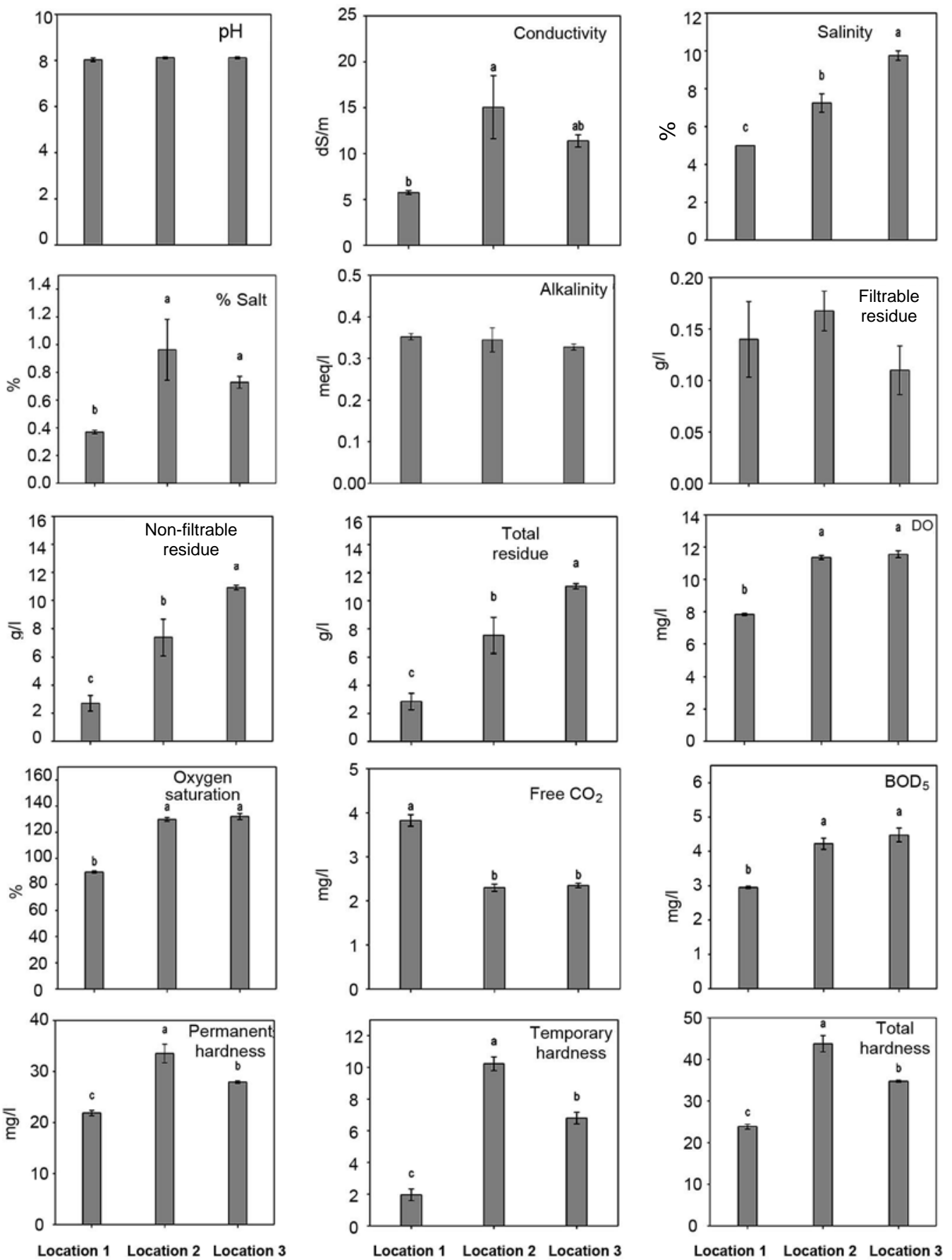

Fig. 1. Location wise variations in the chemical and biological variables of the Buragauranga estuary. Values are in mean with \pm 1 SE. Different letters at the top of the bars indicate that they are significantly different at the $\mathrm{p}=0.05$ level.

(contd.) 
(contd.)
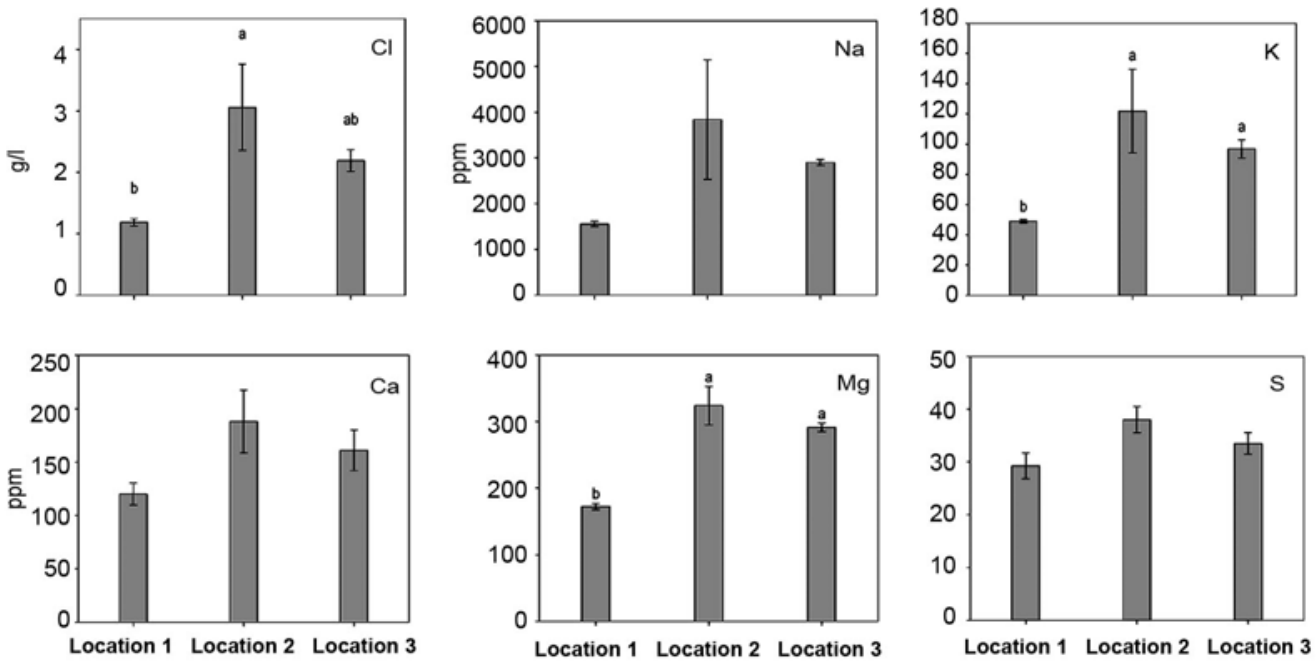

Fig. 1. Location wise variations in the chemical and biological variables of the Buragauranga estuary. Values are in mean with \pm 1 SE. Different letters at the top of the bars indicate that they are significantly different at the $\mathrm{p}=0.05$ level.

environment is the gaseous exchange of atmospheric oxygen across the air-sea surface interface and in situ production by photosynthesis (Best et al. 2007). In estuaries the dynamic pattern of dissolved oxygen is a result of complex interactions among physical, chemical and biological processes (Borsuk et al. 2001). Strong dissolved oxygen gradient is formed in estuaries due to combination of variations in temperature, freshwater discharge, saltwater intrusion, circulation, biological productivity and respiration (Stanley 1993). Higher $\mathrm{BOD}_{5}$ found in the present study in the location 2 than the location 1 may be due to higher number of phytoplankton.

Statistical analysis of the data revealed that conductivity had moderate to very strong and perfect correlations with the variables studied (Table 1). It had perfect positive correlation with $\%$ salt, whereas, had very strong significant correlation with $\mathrm{Na}, \mathrm{K}, \mathrm{Mg}, \mathrm{Cl}$, permanent hardness and total hardness. It has moderate significant correlation with DO, oxygen saturation, free $\mathrm{CO}_{2}$, $\mathrm{BOD}_{5}$ and with temporary hardness. Free $\mathrm{CO}_{2}$ and alkalinity had negative correlations with the factors analyzed except between them. Though the correlation between and alkalinity and other variables are non-significant, free $\mathrm{CO}_{2}$ has significant moderate to very strong correlation with the variables (Table 1). Salinity showed very strong positive significant correlation with DO, oxygen saturation, $\mathrm{BOD}_{5}$, non-filtrable and total residue. It had negative non-significant correlation with filtrable residue. Although it had positive non-significant moderate correlation with the elements studied and with the different fractions of hardness, it had strong significant correlation with Mg. $\mathrm{DO}$, oxygen saturation and $\mathrm{BOD}_{5}$ showed moderate to very strong positive significant correlation with the elements analyzed and different fractions of hardness. The elements had strong to very strong significant correlation among themselves except with Ca. Mg showed very strong relationship with different fractions of hardness whereas Ca had moderate correlation.

In estuaries, phytoplankton assemblage structure and growth are affected by the different environmental factors that include salinity, nutrient, temperature etc. (Morais et al. 2003, Gasiunaite et al. 2005). The assemblage and distribution of phytoplankton and their density in the estuary is shown in Table 2. The phytoplankton community was represented by 10 genera belonging to Chlorophyceae, Euglenophyceae and Bacillariophyceae. The class Bacillariophyceae was represented by 8 genera, whereas Chlorophyceae and Euglenophyceae were represented by 


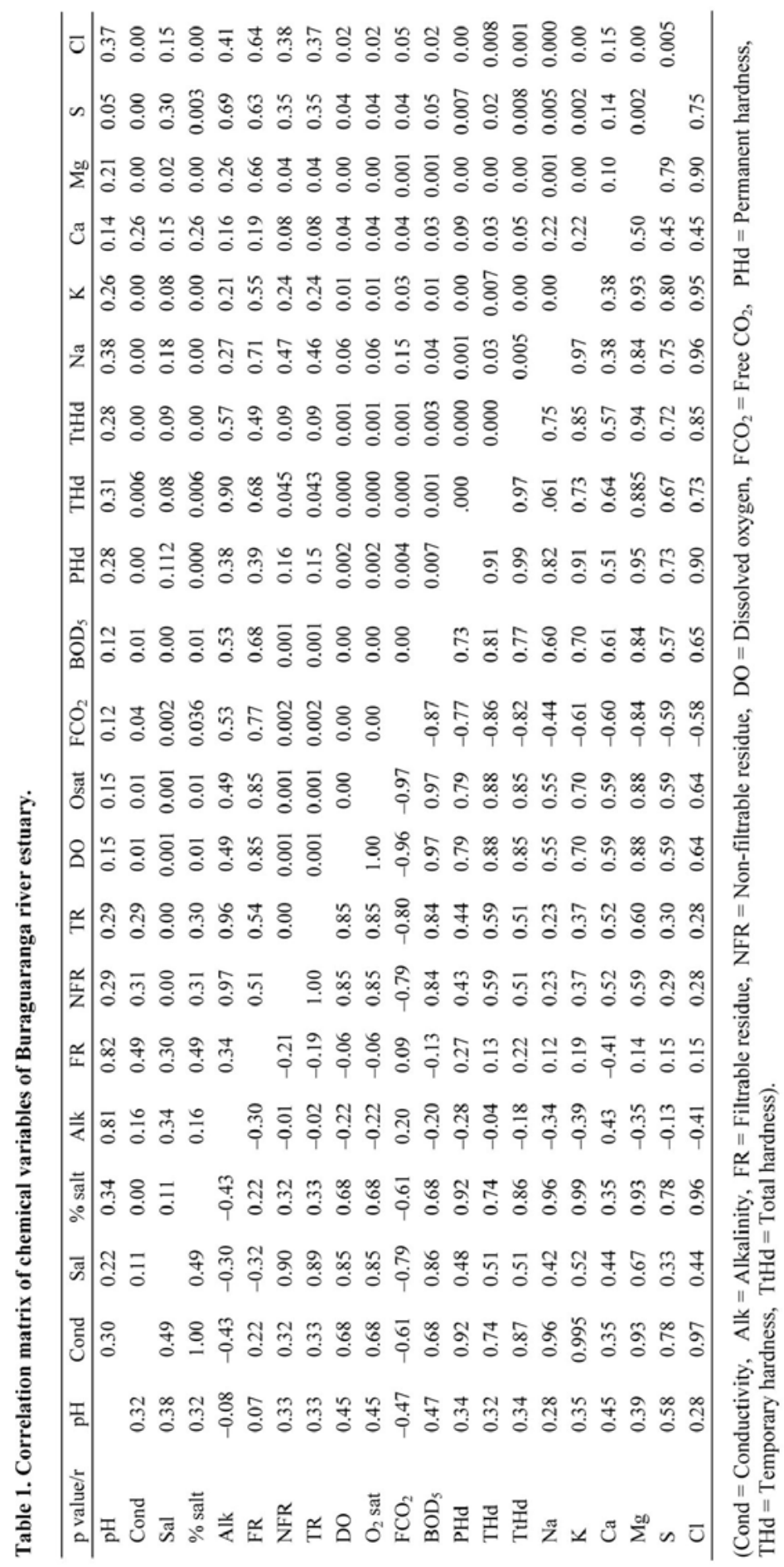




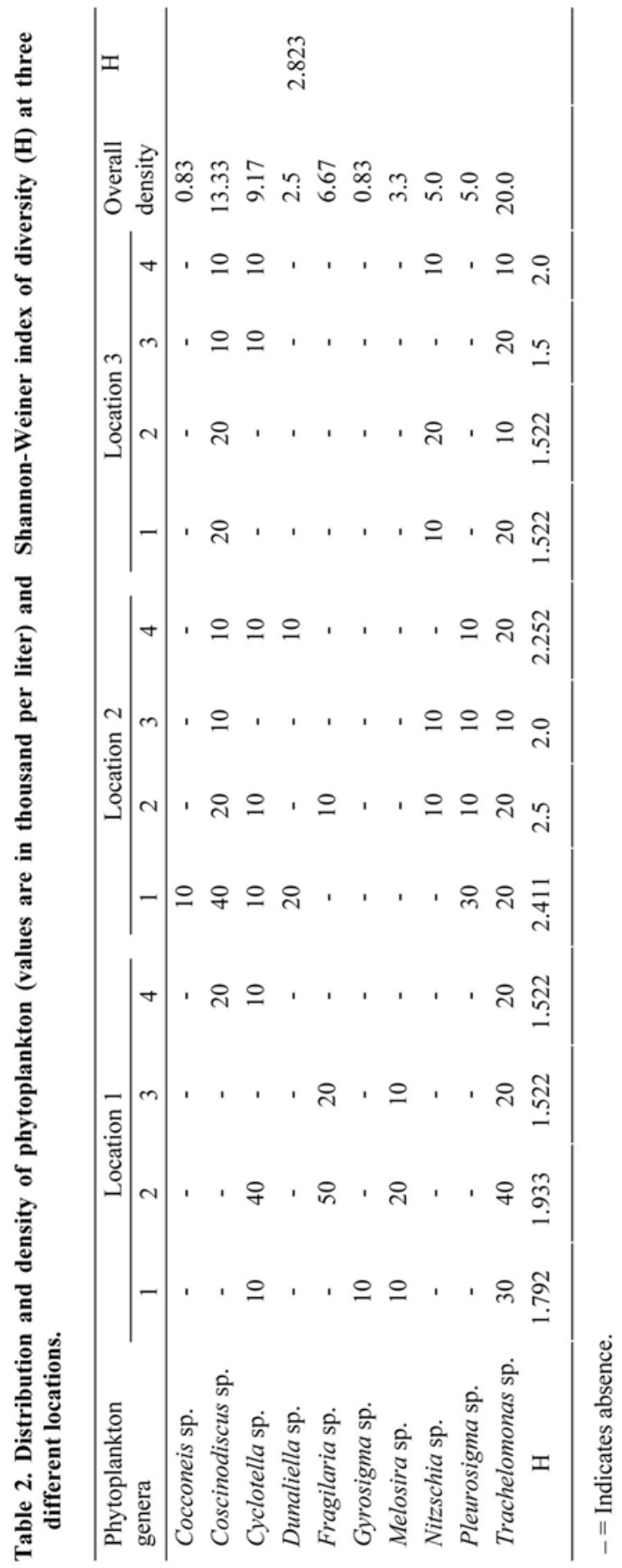


one genus in each. In terms of density Trachelomonas sp. (Euglenophyceae) dominated with $20 \times$ $10^{3}$ individual/l followed by Coscinodiscus sp., Fragilaria sp., and Cyclotella sp. etc. (Bacillariophyceae). Trachelomonas sp. was present in all the 12 sampling units of 3 locations. The only representative of the class Chlorophyceae, Dunaliella sp. $\left(3.3 \times 10^{3}\right.$ individual/l) was present in location 2. The values of Shannon-Weiner index of diversity $(\mathrm{H})$ are also shown in the Table 2 along with values of all sampling units. Different sampling units of location 2 showed higher generic diversity than the other two locations. Quick and unpredictable phytoplankton changes are characteristics of fast-changing ecosystems (Naselli-Flores et al. 2003). It has been revealed from principal component analysis (PCA) that Trachelomonas sp. showed negative correlation with principal component one, that is $\mathrm{Mg}, \mathrm{K}$, conductivity, $\mathrm{DO}, \mathrm{BOD}_{5}$, and salinity has negative effect on the distribution of this algae. On the other hand, Coscinodiscus sp. has shown positive correlation with these variables and negative correlation with free $\mathrm{CO}_{2}$ and alkalinity (Fig. 2).

\begin{tabular}{|c|c|c|c|}
\hline Variable & Compl & comp2 & comp 3 \\
\hline Trachel & -0.166 & 0.2065 & 0.2995 \\
\hline $\mathrm{pH}$ & 0.1315 & -0.0856 & -0.0115 \\
\hline Cond & 0.2369 & 0.2459 & -0.0019 \\
\hline $5 a 1$ & 0.2032 & -0.2642 & -0.2177 \\
\hline salt & 0.2368 & 0.2462 & -0.0023 \\
\hline A.1k & -0.0778 & -0.1946 & 0.6487 \\
\hline $\mathrm{FR}$ & 0.0144 & 0.2977 & -0.2905 \\
\hline NFF & 0.1873 & -0.3492 & -0.1011 \\
\hline TR & 0.1980 & -0.3459 & -0.1057 \\
\hline [0 & 0.2541 & -0.1544 & -0.0526 \\
\hline $025 a t$ & 0.2541 & -0.1543 & -0.0525 \\
\hline $\mathrm{FCOZ}$ & -0.2412 & 0.1762 & 0.0412 \\
\hline $\mathrm{BOO}$ & 0.2476 & -0.1562 & -0.0258 \\
\hline Na & 0.2125 & 0.2688 & 0.0872 \\
\hline$k$ & 0.2395 & 0.2239 & 0.0159 \\
\hline Ca & 0.1629 & -0.1975 & 0.4849 \\
\hline$M g$ & 0.2650 & 0.0840 & -0.0140 \\
\hline$\xi$ & 0.2039 & 0. 1686 & 0.1957 \\
\hline $\mathrm{c}$ & 0.2300 & 0.2423 & 0.0500 \\
\hline PHd & 0.2492 & 0.1536 & 0.0583 \\
\hline $\begin{array}{l}\text { THO } \\
\text { TtHd }\end{array}$ & $\begin{array}{l}0.2418 \\
0.2514\end{array}$ & $\begin{array}{r}-0.0004 \\
0.0934\end{array}$ & 0.1721 \\
\hline
\end{tabular}

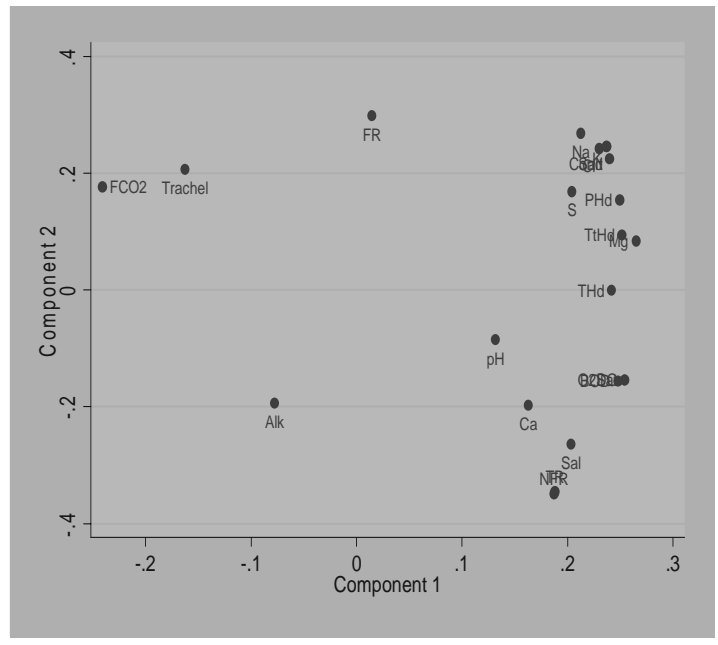

\begin{tabular}{|c|c|c|c|}
\hline Variable & Comp 1 & compz & Comp3 \\
\hline Coscin & 0.1333 & o. 2092 & -0.4825 \\
\hline & 0.1246 & -0.0038 & 0.1909 \\
\hline cond & 0.2415 & 0.2170 & 0. 0873 \\
\hline Sa7 & 0.1989 & -0.2667 & -0.1785 \\
\hline salt & 0.2415 & 0.2174 & 0.0874 \\
\hline A. $\mathrm{k}$ & -0.0807 & -0.2486 & 0.4165 \\
\hline $\mathrm{FR}$ & 0.0212 & 0.3528 & -0.2784 \\
\hline NFR: & 0.1831 & -0.3489 & -0.1920 \\
\hline TR: & 0.1839 & -0.3448 & -0.1967 \\
\hline $\mathrm{QO}$ & 0.2536 & -0.1618 & -0.1163 \\
\hline $025 a t$ & 0.2536 & -0.1617 & -0.1162 \\
\hline $\mathrm{FCO} 2$ & -0.2396 & 0.1775 & 0.1065 \\
\hline BOD & 0.2464 & -0.1754 & -0.0526 \\
\hline $\mathrm{Na}$ & 0.2166 & 0.2268 & 0.2028 \\
\hline k & 0.2436 & 0.1910 & 0.1082 \\
\hline ca & 0.1572 & -0.2494 & 0.4037 \\
\hline $\mathrm{mg}$ & o. 2681 & 0.0670 & -0.0093 \\
\hline$\xi$ & 0. 2061 & 0.1193 & 0. 2810 \\
\hline$c 1$ & 0.2338 & 0.2139 & 0.1374 \\
\hline FHI & 0.2533 & 0.1400 & 0.0319 \\
\hline THI & 0.2451 & -0.0193 & 0.0223 \\
\hline & 0.2553 & $0.07>2$ & 0.0286 \\
\hline
\end{tabular}

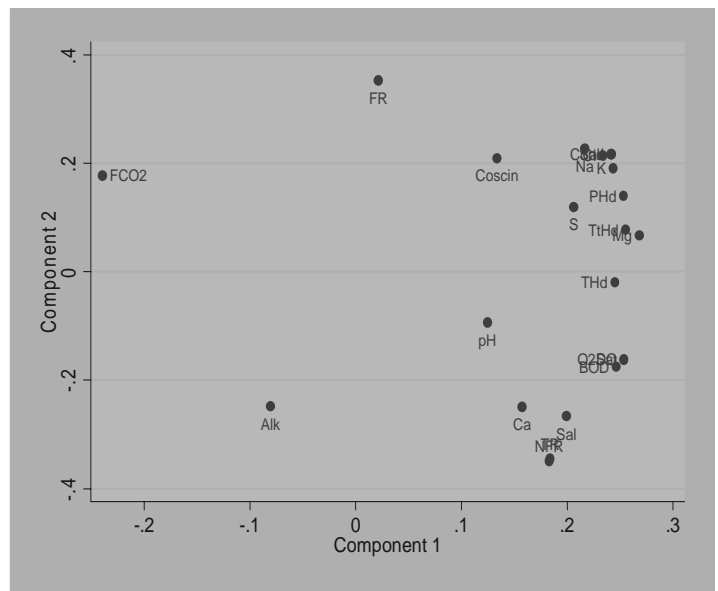

Fig. 2. Principal component analysis showing two significant groupings of variables and their relationship with Trachelomonous sp. and Coscinodiscus sp. (elaboration of the variables are same as Table 1. except Trachel = Trachelomonous sp. and Coscin = Coscinodiscus sp.). 
The distribution of phytoplankton assemblage is often studied in relation to physical and chemical variables like gradient in salinity in coastal ecosystems. It helps in coastal ocean characterization in spatial variability found horizontally or vertically (Lunven et al. 2005). In the present study, phytoplankton structure and assemblage showed an important spatial change in horizontal distribution. Typical river phytoplankton Melosira sp. (Reynolds 1988) were found only in location 1 where the salinity was low. Presence of Trachelomonas sp. in all sampling locations might be due to the capacity of the genus to tolerate habitat fluctuation and free $\mathrm{CO}_{2}$ and alkalinity might have strong effect on their distribution to overcome the influences of the other variables.

\section{Acknowledgements}

Financial support provided by the authority of University of Dhaka, Bangladesh and the Norwegian University of Life Sciences, Ås, Norway for the present research are duely acknowledged. The help of Dr MA Alfasane for identifying phytoplankton is gratefully acknowledged. The authors also thank the staffs of Bangladesh Forest Research Institute, Rangabali station, Patuakhali district for field assistance.

\section{References}

APHA 1976. (American Public Health Association). Standard methods for the examination of water and wastewater. 14th Edn, New York. 1193 pp.

Ahmed A 2004. Ecological studies of the River Padma at Mawa Ghat, Munshiganj. I. Physico-chemical properties. Pak. J. Biol. Sci. 7(11): 1865-1869.

Ahmed A, M Ohlson, S Hoque and GM Moula 2010a. Edaphic conditions of different chars under different hydrological regimes in the coastal zone of Bangladesh. Dhaka Univ. J. Biol. Sci. 19(1): 27-40.

Ahmed A, M Ohlson, S Hoque and GM Moula 2010b. Concentrations of elements in the leaves of a mangrove tree Sonneratia apetala Buch.-Ham. and their correlation with some soil variables. Bangladesh J. Bot. 39(1): 61-69.

Best MA, AW Wither and S Coates 2007. Dissolved oxygen as a physico-chemical supporting element in the Water Framework Directive. Marine Poll. Bull. 55: 53-64.

Borsuk M, CA Stow, RA Luettich, HW Paerl and JL Pinckney 2001. Probabilistic prediction of hypoxia in the Neuse river estuary using an empirical model of oxygen dynamics. Estua. Coast. Shelf Sci. 52: 33-49.

Caccia VG and JN Boyer 2005. Spatial patterning of water quality in Biscayne Bay, Florida as a function of land use and water management. Marine Poll. Bull. 50: 1416-1429.

Caffrey JM, TP Chapin, HW Jannasch and JC Haskins 2007. High nutrient pulses, tidal mixing and biological response in a small California estuary: variability in nutrient concentrations from decadal to hourly time scales. Estua. Coast. Shelf Sci. 71: 368-380.

Chen Z, M Watanabe and E Wolanski 2007. Sedimentological and ecohydrological processes of Asian deltas: the Yangtze and the Mekong. Estua. Coast. Shelf Sci. 71: 1-2.

Corbett DR, D Vance, E Letrick, D Mallinson and S Culver 2007. Decadal-scale sediment dynamics and environmental change in the Albemarle estuarine system, North Carolina. Estua. Coast. Shelf Sci. 71: 717-729.

Gasiunaite ZR, AC Cardoso, AS Heiskanen, P Henriksen, P Kauppila, I Olenina, R Pikaityte, I Purina, A Razinkovas, S Sagert, H Schubert and N Wasmund 2005. Seasonality of coastal phytoplankton in the Baltic Sea: influence of salinity and eutrophication. Estua. Coast. and Shelf Sci. 65: 239.252.

Hunt J 1980. Determination of total sulphur in small amount of plant material. Analyst. 105: 83-85.

Islam AKMN and A Aziz 1975. Study of marine phytoplankton from the North-Eastern Bay of Bengal, Bangladesh. Bangladesh J. Bot. 4(2): 1-32. 
Islam AKMN and A Aziz 1977. Studies of the phytoplankton of the Karnaphuli river estuary. J. Bangladesh Acad. Sci. 1(2): 141-154.

Islam MS 2001. Sea level changes in Bangladesh: the last ten thousand years. Asiat. Soc. Bangladesh, Dhaka.

Krey JBB 1976. Phytoplankton production atlas of the international Indian Ocean expedition. IOC/UNESCO. 70 pp.

Lakshminarayana JSS 1965. Studies on the phytoplankton of the river Ganges, Varanasi, India. Part I and II. Hydrobiologia. 25: 119-164.

Lunven M, JF Guillaud, A Youénou, MP Crassous, R Berric, EL Gall, R Kérouel, C Labry, A Aminot 2005. Nutrient and phytoplankton distribution in the Loire river plume (Bay of Biscay, France) resolved by a new Fine Scale Sampler. Estua. Coast. Shelf Sci. 65: 94-108.

Morais P, MA Chicharo and A Barbosa 2003. Phytoplankton dynamics in a coastal saline lake (SE-Portugal). Acta Oecol. 24: S87-S96.

Naselli-Flores L, J Padisa'k, MT Dokulil and I Chorus 2003. Equilibrium/steady-state concept in phytoplankton ecology. Hydrobiologia 502: 395-403.

Painting SJ, MJ Devlina, SJ Malcolma, ER Parkera, DK Millsa, C Millsa, P Tettb, A Witherc, J Burtd, R Jonese and K Winpennya 2007. Assessing the impact of nutrient enrichment in estuaries: susceptibility to eutrophication. Marine Poll. Bull. 55:74-90.

Reynolds CS 1988. Potamoplankton: paradigms, paradoxes and prognoses. Biopress Ltd., Bristol.

Ruggiero MA and HC Merchant 1979. Water quality, substrate and distribution of macroinvertebrates in the Partuxent River, Maryland. Hydrobiologia 64: 183-189.

Stanley DW 1993. Long-term trends in Pamlico river estuary nutrients, chlorophyll, dissolved oxygen and watershed nutrient production. Water Resour. Res. 29: 2651-2662.

Stata Corp 2010. Stata statistical software: release 11. Stata Corp LP, College Station, TX. URL http://www.stata.com/.

Wetzel RG and GE Likens 1979. Limnological analysis. WB Saunders Co., Philadelphia. 357 pp.

Wyritki K 1971. Oceanographic atlas of the international Indian Ocean expedition. National Science Foundation, Washington, DC, 531pp.

(Manuscript received on15 March, 2010; revised on 24 November, 2010) 